\title{
Extraction of Fat and Fatty Acid Composition from Slaughterhouse Waste by Evaluating Conventional Analytical Methods
}

\author{
Ariba Khan1, Farah Naz Talpur ${ }^{*}{ }^{\circledR}$, Muhammad Iqbal Bhanger ${ }^{2}$, Syed Ghulam Musharraf², \\ Hassan Imran Afridi ${ }^{1}$ \\ ${ }^{1}$ National Centre of Excellence in Analytical Chemistry, University of Sindh, Jamshoro, Pakistan \\ ${ }^{2}$ Hussain Ebrahim Jamal Research Institute of Chemistry, International Centre for Chemical and Biological Sciences, \\ University of Karachi, Karachi, Pakistan \\ Email: ^farahtalpur@hotmail.com
}

How to cite this paper: Khan, A., Naz Talpur, F., Bhanger, M.I., Musharraf, S.G. and Afridi, H.I. (2021) Extraction of Fat and Fatty Acid Composition from Slaughterhouse Waste by Evaluating Conventional Analytical Methods. American Journal of Analytical Chemistry, 12, 202-225.

https://doi.org/10.4236/ajac.2021.125013

Received: April 8, 2021

Accepted: May 28, 2021

Published: May 31, 2021

Copyright $\odot 2021$ by author(s) and Scientific Research Publishing Inc. This work is licensed under the Creative Commons Attribution International License (CC BY 4.0).

http://creativecommons.org/licenses/by/4.0/

(c) (i) Open Access

\begin{abstract}
To attain maximum recovery of useful compounds from slaughterhouse waste (Suet, Tongue, Pancreas) of selected ruminant (cow, goat, lamb, and bull), the fat extraction efficiency of popular methods was compared along with fatty acid (FAs) composition. Four selected methods including Soxhlet (SOX), acid hydrolysis, Bligh \& dyer (B\&D), and Folch (FOL) were assessed. After methylation, extracted lipids were analyzed by Gas chromatography for FA composition. Data indicated that all selected methods were significantly $(\mathrm{p}<$ 0.05) different from each other, particularly higher differences were noticed for low lipid-containing products (Tongue, Pancreas) as well as their respective FA Composition. Based on Analysis of Variance and Principal component analysis, the effective method for lipid and FA Composition analysis was the FOL method. The Soxhlet method was only effective for samples with high-fat content i.e., suet, while the B\&D method gave comparatively low lipid content in analyzed samples. Hence based on the results, excellent fat and fatty acid extraction was achieved with the FOL method.
\end{abstract}

\section{Keywords}

Fatty Acid, Slaughterhouse Waste, Animal by-Products, Extraction Methods, Lipid Analysis, Gas Chromatography

\section{Introduction}

The generation of waste is a fundamental part of the manufacturing of food products for human utilization. Slaughterhouse waste is described as an animal carcass component formed during the cutoff of meat for food processing. The 
sources of waste are numerous including restaurants, slaughterhouses, stores, and farms [1]. The nature and amount of waste are different at each step of production, the slaughterhouse products can be classified into four groups 1) the high worth product meat; 2) the inedible part which can be utilized for industrial purposes (for instance bones, hides, blood and hooves; 3) low-cost stuffing (offal); and 4) items having no use (digestive tract matter, slaughterhouse effluent) are predisposed as garbage [2].

Conversion of animals slaughtering waste ( $17 \%-28 \%$ of live animal weight) into bioactive compound production has a direct impact on the meat processing industry, which can generate nearly identical revenue to the worth of the meat obtained from an animal if used properly. The cumulative meat production of the world is on the rise by $1.9 \%$ per year, according to the Food and Agriculture Organization (FAO) of the United Nations, except for China [3]. With the production of meat increasing, the proportion of by-products is also on the rise. The rendering industry produces raw materials for animal and pet food by utilizing parts of the waste material, mostly offal. The rendering process also results in primary products like meat meal, hydrolyzed feather meal, Meat and bone meal (MBM), fish meal, poultry meal, blood meal, and animal fats [4]. The consumption of organ meat is dependent upon different regions, which depends upon factors like religion, tradition, and culture of said area. The meat industry utilizes edible by-products as value-added and functional ingredients. Additionally, significant amounts of essential fatty acids (FAs), vitamins, amino acids, and minerals may be availed by edible meat by-products [5]

Contemporary developments on the exploitation of slaughterhouse by-products in several applications include the use as feedstock for anaerobic digestion [6] [7] [8] [9], for recovery of bioactive peptides [2], for production of processed food for human consumption [10], lipids/fats and enzymes, as a source of protein hydrolysate [11]. Animal fats, edible vegetable oils, marine oils, palm oils, and industrial oils are major sources of fats and oils. About three-fourths of the world's oil and fats were used for food applications. However, recent trends showed a shift from food to industrial uses, especially in biodiesel [12].

A variety of methods have been established for the extraction of lipid, the officially recommended Association of Analytical Chemists method (AOAC), and the most common one used for meat and its products, is the Soxhlet method (SOX). Folch et al. (1957) (FOL) and Bligh and Dyer (1959) (B\&D) described approaches built on the use of a mixture of methanol and chloroform. In addition, there are different modes of extraction available in new Soxhlet extraction systems that might help to enhance the extraction process, minimizing the solvent volume and the extraction time [13]. In addition, the fat content determined by cold extraction methods or Soxhlet procedure is not exactly related to meat stuff s fat value. Inaccurate estimation of the energy value is depicted because of soaps that are not extracted or nonnutritive pigments and waxes that are also extracted [14].

However, for the ruminant (beef, goat, lamb, etc.) by-products, the data on Fatty acid composition is still somewhat scarce [5]. Subsequently, extensive 
amounts of slaughterhouse by-products are being landfilled or incinerated. Not only this is very harmful to the environment, but it is also causing the meat industry some economic loss and additional production costs [15]. Therefore, it is essential to discover novel ways to attain maximum yield for slaughterhouse by-products, also a growing appeal lies in budding platforms for exploitation of such slaughterhouse waste in value-added industrial applications. Hence, the key purpose of the current study was to assess and compare the different extraction methods for FA composition in the most common animals' by-products (pancreas and tongue, suet) from selected animals like cows, goat, lamb, and bulls, as these are the most commonly consumed animals and said waste parts were reported to have most fat.

\section{Materials and Methods}

\subsection{Chemical and Reagents}

All reagents used were of analytical standard. Hexane, methanol, chloroform, hydrochloric acid, and potassium hydroxide were purchased from Sigma-Aldrich (Steinheim, Germany) \& Merck (Darmstadt, Germany). Milli Q Plus (Millipore SA, France) water treatment system was used for producing Deionized water. Standards of fatty acid methyl esters (FAME) were acquired from Sigma Aldrich (St. Louis, MO, USA). Standards were dissolved in hexane and injected into a gas chromatograph for analysis.

\subsection{Sampling}

Three types of meat by-products i.e., Suet, Tongue, Pancreas from four ruminants (cow, goat, lamb, and bull) were $(\mathrm{n}=72)$ selected from the slaughterhouse of Hyderabad and Karachi (Sindh, Pakistan). Samples were put on ice immediately after collection and they were transported to the laboratory, where they were washed and stored at $-18^{\circ} \mathrm{C}$ for further analysis.

\subsection{Instrumentation}

Fatty acid analysis was done on a Perkin Elmer gas chromatograph 8700 fitted with FID detector. SP-2340 fused silica capillary column $(30 \mathrm{~m} \times 0.25 \mathrm{~mm} \times 0.2$ $\mu \mathrm{m}$ ) (Supelco, Inc., Bellefonte, $\mathrm{PA}$ ) was employed, with temperature programmed from $120^{\circ} \mathrm{C}$ to $220^{\circ} \mathrm{C}$ at $4^{\circ} \mathrm{C} / \mathrm{min}$. Nitrogen as carrier gas was used at a flow rate of $3.5 \mathrm{~mL} / \mathrm{min}$. The injector and detector temperature were set at $260^{\circ} \mathrm{C}$ and $270^{\circ} \mathrm{C}$ respectively. Fatty acids were identified by comparison of their retention times with that of the authentic standard and retention times. A built-in data handling program provided by the manufacturer of the gas chromatograph (Perkin-Elmer) was used for all quantifications as reported earlier [16].

\subsection{Sample Preparation}

\subsubsection{Extraction Methods}

For fat extraction, four different methods were followed 1) Soxhlet Method; 2) 
Acid hydrolysis; 3) Bligh and Dyer; 4) Folch Method. Each Analysis was done in triplicates. The experimental layout is presented in Figure 1.

\section{1) Soxhlet Extraction (SOX)}

For fat extraction, AOAC method 960.39 was employed [17]. The weighted samples of $5 \mathrm{~g}$ were placed into a cellulose thimble and dried to eliminate any excess moisture. Hexane was used as an extracting solvent. The extraction process was continued for about 4 hours at $70^{\circ} \mathrm{C}$. After complete extraction, the solvent was evaporated, dried, and weighed gravimetrically.

\section{2) Acid Hydrolysis}

AOAC Method 954.02 was employed for fat extraction. Briefly, samples were hydrolyzed with $8.3 \mathrm{~mol} / \mathrm{L}$ hydrochloric acid and transferred to mojonnier flask. Hexane and ethyl ether were added for further fat extraction. Extracts were dried, reconstituted in hexane, and filtered through a column of sodium sulfate. The filtered extracts were then evaporated, dried, and weighed [18] [19].

\section{3) Bligh-Dyer Method (B\&D)}

$5 \mathrm{~g}$ of sample were taken with $15 \mathrm{~mL}$ of methanol: chloroform $(2: 1, \mathrm{v} / \mathrm{v})$, following the original method [20]. The concoction was then homogenized and centrifuged at $3000 \mathrm{rpm}$ for 10 minutes. After filtering the mixture, $5 \mathrm{~mL}$ of chloroform was added to the residue, centrifuged again ( $3000 \mathrm{rpm}, 10 \mathrm{~min})$ then filtered and collected with the previous filtrate. $5 \mathrm{~mL}$ of distilled water was added to this mixture. After shaking, the mixture was centrifuged (3000 rpm, $10 \mathrm{~min}$ ) to allow layer separation. The aqueous layer (upper) was removed. The chloroformic layer (lower) was passed through sodium sulphate (anhydrous). The fat content was calculated after chloroform was evaporated and further dried.

\section{4) Folch Method (FOL)}

Using the original extraction ratio of 20 parts solvent to 1-part sample, $5 \mathrm{~g}$ of sample was mixed with $100 \mathrm{~mL}$ of methanol: chloroform (1:2 v/v). The sample was homogenized and centrifuged at $3000 \mathrm{rpm}$ for 10 minutes. After filtering the

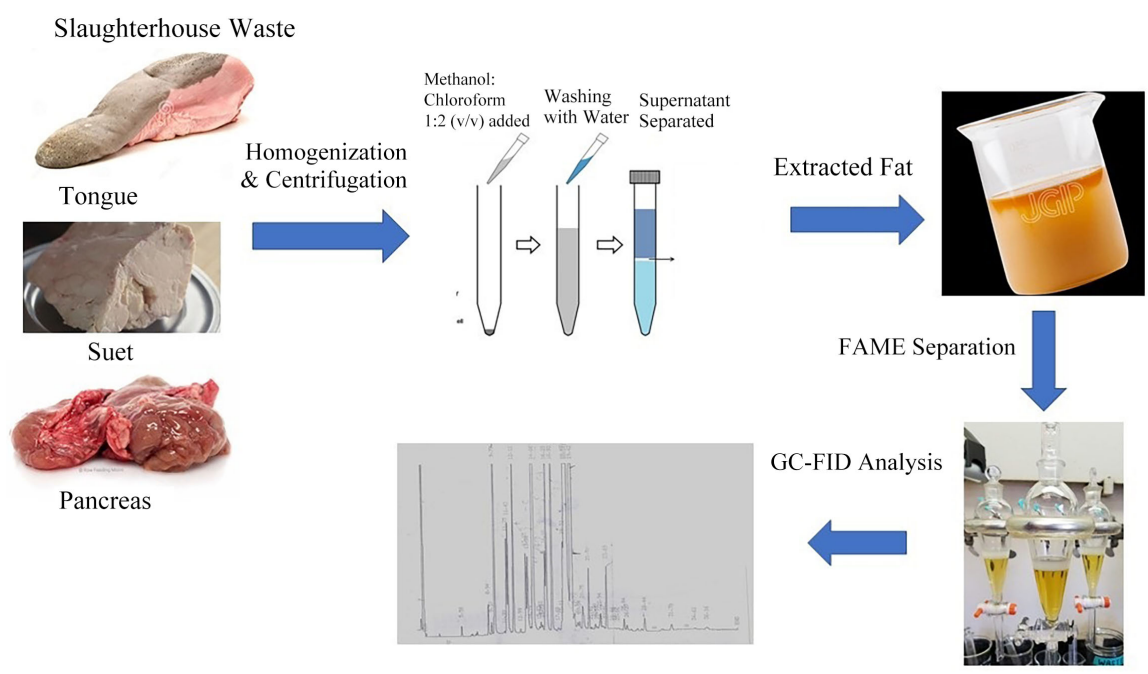

Figure 1. Experimental layout of extraction of fat and fatty acids from slaughterhouse waste. 
sample, $5 \mathrm{~mL}$ of distilled water was added to filtered extracts and was shaken vigorously. Once again, the sample was centrifuged (3000 rpm, $10 \mathrm{~min}$ ) to allow the layer to separate. The aqueous layer (upper layer) was discarded. The chloroformic layer (lower layer) was separated and filtered over anhydrous sodium sulphate. The filtered extracts were evaporated, dried and then weighed [21].

\subsubsection{Preparation of Fatty Acid Methyl Ester}

Fatty acid methyl esters (FAME) were prepared according to the reported method [22]. Briefly, $50 \mathrm{mg}$ of extracted fat was refluxed with $2 \mathrm{~mL}$ of $2 \mathrm{M}$ methanolic $\mathrm{KOH}$ and $20 \mathrm{~mL}$ methanol at $80^{\circ} \mathrm{C}$ for an hour. After cooling the samples, $2 \mathrm{~mL}$ of $25 \%$ boron trifluoride $(\mathrm{BF} 3)$ solution in methanol was added and heated again for an hour. $5 \mathrm{~mL}$ of $\mathrm{n}$-hexane and water each was added to the cooled sample and shaken vigorously allowing two separate layers to form in a separating funnel. Upper layer was recovered and passed through a layer of anhydrous sodium sulphate and stored in sealed GC vials at $-20^{\circ} \mathrm{C}$ until further GC analysis.

\subsection{Statistical Analysis}

Analysis of Variance (ANOVA) was used to statistically compare the results of fatty acid in various samples. To compare the variance in the results from each method, a test for equal variances was performed. All statistical analysis was performed at a 95\% confidence level. Principal component analysis (PCA) was carried out using the Minitab software (Minitab 17, Minitab Inc., State College, PA, USA).

\section{Results}

The amount of fat extracted from ruminant by-products (Suet, Tongue, Pancreas) through different methods is presented in Table 1.

Table 1. Total lipid content $(\mathrm{g} / 100 \mathrm{~g})$ of meat by-products obtained by four different lipid extraction methods.

\begin{tabular}{cccccc}
\hline \multicolumn{2}{c}{ Method } & SOX & Acid Hydrolysis & B\&D & FOL \\
\hline \multirow{3}{*}{ Cow } & Tongue & $10.7 \pm 0.19$ & $15.4 \pm 0.08$ & $12.6 \pm 0.14$ & $18.2 \pm 0.07$ \\
& Suet & $95.3 \pm 0.14$ & $87.1 \pm 0.16$ & $84.1 \pm 0.23$ & $96.2 \pm 0.05$ \\
& Pancreas & $11.6 \pm 0.23$ & $15.2 \pm 0.11$ & $14.7 \pm 0.11$ & $18.4 \pm 0.04$ \\
\hline \multirow{3}{*}{ Goat } & Tongue & $7.6 \pm 0.53$ & $13.1 \pm 0.05$ & $10.3 \pm 0.27$ & $15.2 \pm 0.08$ \\
& Suet & $93.1 \pm 0.12$ & $90.5 \pm 0.19$ & $80.6 \pm 0.13$ & $93.8 \pm 0.01$ \\
& Pancreas & $6.9 \pm 0.16$ & $8.7 \pm 0.21$ & $7.5 \pm 0.18$ & $9.6 \pm 0.09$ \\
\multirow{3}{*}{ Lamb } & Tongue & $11.1 \pm 0.44$ & $14.5 \pm 0.39$ & $11.2 \pm 0.32$ & $17.8 \pm 0.04$ \\
& Suet & $90.6 \pm 0.22$ & $86.3 \pm 0.09$ & $75.4 \pm 0.40$ & $92.3 \pm 0.10$ \\
& Pancreas & $7.4 \pm 0.49$ & $9.2 \pm 0.13$ & $8.8 \pm 0.23$ & $10.4 \pm 0.05$ \\
\hline \multirow{3}{*}{ Bull } & Tongue & $10.2 \pm 0.37$ & $16.4 \pm 0.04$ & $12.5 \pm 0.41$ & $15.8 \pm 0.05$ \\
& Suet & $88.2 \pm 0.31$ & $83.1 \pm 0.07$ & $79.6 \pm 0.19$ & $90.5 \pm 0.02$ \\
& Pancreas & $8.7 \pm 0.12$ & $18.0 \pm 0.15$ & $10.3 \pm 0.24$ & $17.2 \pm 0.07$ \\
\hline
\end{tabular}


Result showed that four extraction methods differed significantly $(\mathrm{p}<0.05)$ in total lipids extracted for analyzed meat by-products. For almost all the by-products (except suet) FOL method extracted the highest amount of lipids followed by acid hydrolysis and the SOX \& B\&D method showing the lowest levels of total extracted lipids. However, for bull's tongue and pancreas (B.T, B.P), acid hydrolysis extracted a higher amount of lipid $(16.4,18.0 \mathrm{~g} / 100 \mathrm{~g}$ respectively) than FOL (15.8, $17.2 \mathrm{~g} / 100 \mathrm{~g}$ respectively). For suet, unlike other samples, FOL and SOX extracted a higher amount of fat than their counterparts. Here SOX showed better extraction than acid hydrolysis with higher yields of total fat in cow, goat, lamb, and bull (C.S, G.S, L.S \& B.S 95.3, 93.1, 90.6, $88.2 \mathrm{~g} / 100 \mathrm{~g}$ ) than acid hydrolysis $(87.1,90.5,86.3,83.1 \mathrm{~g} / 100 \mathrm{~g})$. B\&D method underestimated and extricated less amounts of lipids (for suet) than the other three methods.

The Fatty acid composition of ruminant meat samples by-products, extracted through different methods, were determined by Gas Chromatography (GC) and the results of Cow's tongue, suet, and pancreas are presented in Tables 2-5, while FA profiles of other ruminants (Goat, Lamb and Bull) are presented as supporting information in Tables S6-S13.

It can be seen that yield of FAs varied with different methods along with the recovery of FAs, in terms of sample percentage. For C.T, 63\% of the lipid was recovered, whereas by acid hydrolysis, B\&D and FOL the FAs recovery was $82 \%$, $71 \%$ and $90 \%$ respectively. A similar trend can be noted in other tongue samples with the exception of bull (B.T), where through acid hydrolysis the highest yield $(15.32 \mathrm{~g} / 100 \mathrm{~g})$ was extracted followed by FOL (14.97 g/100g). For C.S, the results were a little different than other samples trend, both FOL and SOX performed better with optimum yield as 85.58 and $80.32 / 100 \mathrm{~g}$ than other two methods investigated. Similar results were discovered for B.S, G.S and L.S, where SOX extraction efficiency improved considerably. By looking at the tables, it can be seen that a trend was forming, where for C.P, G.P, L.P, the analyzed FAs were in similar order, with FOL extracting the highest $(16.06,8.47 \& 9.27 \mathrm{~g} / 100 \mathrm{~g}$ respectively), followed by acid hydrolysis $(13.49,8,7.97 \mathrm{~g} / 100 \mathrm{~g}$ respectively) and B\&D (11.25, 5.83, $7.07 \mathrm{~g} / 100 \mathrm{~g}$ respectively). Like the pattern observed for B.T, B.P yielded FAs in a similar manner. FAs extracted through acid hydrolysis (15.32 $\mathrm{g} / 100 \mathrm{~g}$ ) produced higher results as compared to FOL (14.97 g/100g), while B\&D and SOX were close, although not significant with $7.42 \mathrm{~g} / 100 \mathrm{~g}$ and $6.06 \mathrm{~g} / 100 \mathrm{~g}$, respectively.

A PCA score plot of all FA profiles is shown in Figure 2(a). Through this plot, any differences and similarities between the samples can be seen. Compared to the differences between the samples, all the results extracted through different method for same sample are clustered in a group. The only outliers are the suet samples, which are very high in lipid content. Figure 2(b) shows the PCA score plot which shows the difference between each extraction method; FOL and acid hydrolysis occupied in one component while SOX and B\&D are in the other with $50 \%$ of variance. This also verifies to the judgements that can be drawn 
from the Euclidean distances, that FOL and acid hydrolysis are better suited methods for meat by-products.

Table 2. Mean fatty acid composition (g/100g of sample) of Cow's tongue determined by selected methods.

\begin{tabular}{|c|c|c|c|c|}
\hline FAME & sox & Acid Hydrolysis & B\&D & FOL \\
\hline $\mathrm{C} 8: 0$ & n.a. & n.a. & n.a. & 0.007 \\
\hline $\mathrm{C} 10: 0$ & n.a. & n.a. & n.a. & n.a. \\
\hline C12:0 & 0.04 & 0.08 & 0.06 & 0.13 \\
\hline C14:0 & 0.17 & 0.30 & 0.23 & 0.42 \\
\hline C15:0 (iso) & 0.02 & 0.08 & 0.05 & 0.11 \\
\hline C15:0 (anteiso) & 0.05 & 0.12 & 0.09 & 0.16 \\
\hline C15:0 & 0.09 & 0.17 & n.a. & n.a. \\
\hline C16:0 & 1.47 & 2.92 & 2.10 & 3.89 \\
\hline C17:0 (iso) & 0.09 & 0.18 & 0.13 & 0.24 \\
\hline C17:0 (anteiso) & 0.04 & 0.09 & 0.07 & 0.13 \\
\hline $\mathrm{C} 17: 0$ & 0.20 & 0.40 & 0.29 & 0.53 \\
\hline C18:0 & 1.04 & 1.97 & 1.42 & 2.58 \\
\hline C20:0 & 0.02 & 0.06 & 0.04 & 0.07 \\
\hline $\mathrm{C} 22: 0$ & n.a. & 0.001 & n.a. & n.a. \\
\hline C14:1 & 0.05 & 0.11 & 0.07 & 0.14 \\
\hline $\mathrm{C} 16: 1 \mathrm{c}$ & 0.23 & 0.46 & 0.32 & 0.60 \\
\hline $\mathrm{C} 16: 1 \mathrm{t}$ & 0.04 & 0.09 & 0.05 & 0.11 \\
\hline $\mathrm{C} 17: 1 \mathrm{c}$ & 0.17 & 0.35 & 0.25 & 0.45 \\
\hline $\mathrm{C} 17: 1 \mathrm{t}$ & 0.06 & 0.12 & 0.09 & 0.16 \\
\hline $\mathrm{C} 18: 1 \mathrm{c}$ & 2.31 & 3.95 & 2.77 & 5.18 \\
\hline $\mathrm{C} 18: 1 \mathrm{t}$ & 0.24 & 0.44 & 0.31 & 0.53 \\
\hline C20:1 & 0.03 & 0.06 & 0.04 & 0.08 \\
\hline C22:1 & 0.05 & 0.09 & 0.07 & 0.12 \\
\hline $\mathrm{C} 18: 2$ & 0.16 & 0.31 & 0.22 & 0.34 \\
\hline $\mathrm{C} 18: 3$ & 0.06 & 0.12 & 0.09 & 0.16 \\
\hline $\mathrm{t} 10, \mathrm{c} 12 \mathrm{CLA}$ & 0.03 & 0.07 & 0.05 & 0.09 \\
\hline c9, t11 CLA & 0.08 & 0.15 & 0.11 & 0.17 \\
\hline $\mathrm{C} 20: 4$ & 0.02 & 0.04 & 0.03 & 0.05 \\
\hline SFA & 3.23 & 6.37 & 4.48 & 8.27 \\
\hline MUFA & 3.18 & 5.67 & 3.97 & 7.37 \\
\hline PUFA & 0.35 & 0.69 & 0.50 & 0.81 \\
\hline Total FA & 6.76 & 12.73 & 8.95 & 16.45 \\
\hline
\end{tabular}


A. Khan et al.

Table 3. Mean fatty acid composition (g/100g of sample) of Goat's tongue determined by selected methods.

\begin{tabular}{|c|c|c|c|c|}
\hline FAME & sox & Acid Hydrolysis & B\&D & FOL \\
\hline C8:0 & 0.04 & n.a. & 0.02 & 0.04 \\
\hline C10:0 & n.a. & n.a. & n.a. & n.a. \\
\hline C12:0 & n.a. & n.a. & n.a. & n.a. \\
\hline C14:0 & 0.07 & 0.14 & 0.11 & 0.19 \\
\hline C15:0 (iso) & 0.01 & 0.02 & 0.02 & 0.03 \\
\hline C15:0 (anteiso) & 0.01 & 0.02 & 0.02 & 0.04 \\
\hline C15:0 & 0.02 & 0.04 & 0.03 & 0.06 \\
\hline $\mathrm{C} 16: 0$ & 1.23 & 2.52 & 1.90 & 3.18 \\
\hline C17:0 (iso) & n.a. & n.a. & n.a. & n.a. \\
\hline C17:0 (anteiso) & n.a. & n.a. & n.a. & n.a. \\
\hline C17:0 & 0.07 & 0.15 & 0.11 & 0.19 \\
\hline $\mathrm{C} 18: 0$ & 1.01 & 2.07 & 1.56 & 2.63 \\
\hline C20:0 & 0.01 & 0.03 & 0.03 & 0.05 \\
\hline $\mathrm{C} 22: 0$ & n.a. & n.a. & n.a. & n.a. \\
\hline C14:1 & 0.03 & 0.05 & 0.04 & 0.08 \\
\hline $\mathrm{C} 16: 1 \mathrm{c}$ & 0.09 & 0.18 & 0.14 & 0.24 \\
\hline $\mathrm{C} 16: 1 \mathrm{t}$ & 0.009 & 0.02 & 0.02 & 0.03 \\
\hline $\mathrm{C} 17: 1 \mathrm{c}$ & 0.07 & 0.14 & 0.11 & 0.19 \\
\hline $\mathrm{C} 17: 1 \mathrm{t}$ & 0.02 & 0.03 & 0.03 & 0.07 \\
\hline $\mathrm{C} 18: 1 \mathrm{c}$ & 2.23 & 4.55 & 3.41 & 5.69 \\
\hline $\mathrm{C} 18: 1 \mathrm{t}$ & 0.11 & 0.21 & 0.16 & 0.27 \\
\hline C20:1 & 0.008 & 0.01 & 0.01 & 0.03 \\
\hline C22:1 & 0.02 & 0.02 & 0.02 & 0.03 \\
\hline C18:2 & 0.11 & 0.25 & 0.20 & 0.35 \\
\hline $\mathrm{C} 18: 3$ & 0.007 & 0.01 & 0.01 & 0.03 \\
\hline $\mathrm{t} 10, \mathrm{c} 12 \mathrm{CLA}$ & 0.007 & 0.01 & 0.01 & 0.02 \\
\hline c9, t11 CLA & 0.01 & 0.03 & 0.02 & 0.04 \\
\hline C20:4 & 0.02 & 0.03 & 0.05 & 0.05 \\
\hline SFA & 2.47 & 5.02 & 3.80 & 6.41 \\
\hline MUFA & 2.59 & 5.21 & 3.94 & 6.63 \\
\hline PUFA & 0.15 & 0.33 & 0.29 & 0.49 \\
\hline Total FA & 5.21 & 10.56 & 8.03 & 13.53 \\
\hline
\end{tabular}


Table 4. Mean fatty acid composition ( $\mathrm{g} / 100 \mathrm{~g}$ of sample) of Lamb's tongue determined by selected methods.

\begin{tabular}{|c|c|c|c|c|}
\hline FAME & sox & Acid Hydrolysis & $B \& D$ & FOL \\
\hline $\mathrm{C} 8: 0$ & 0.06 & n.a. & 0.07 & 0.13 \\
\hline $\mathrm{C} 10: 0$ & n.a. & n.a. & n.a. & n.a. \\
\hline $\mathrm{C} 12: 0$ & n.a. & n.a. & n.a. & n.a. \\
\hline C14:0 & 0.07 & 0.13 & 0.09 & 0.18 \\
\hline C15:0 (iso) & 0.02 & 0.02 & 0.02 & 0.03 \\
\hline C15:0 (anteiso) & 0.01 & 0.04 & 0.02 & 0.04 \\
\hline $\mathrm{C} 15: 0$ & 0.03 & 0.06 & 0.04 & 0.08 \\
\hline $\mathrm{C} 16: 0$ & 1.42 & 2.17 & 1.53 & 2.91 \\
\hline C17:0 (iso) & 0.02 & 0.02 & 0.02 & 0.05 \\
\hline C17:0 (anteiso) & 0.03 & 0.04 & 0.03 & 0.06 \\
\hline $\mathrm{C} 17: 0$ & 0.12 & 0.19 & 0.13 & 0.26 \\
\hline C18:0 & 1.81 & 2.79 & 1.95 & 3.72 \\
\hline C20:0 & 0.05 & 0.07 & 0.05 & 0.10 \\
\hline $\mathrm{C} 22: 0$ & n.a. & n.a. & n.a. & n.a. \\
\hline C14:1 & 0.01 & 0.02 & 0.02 & 0.03 \\
\hline $\mathrm{C} 16: 1 \mathrm{c}$ & 0.12 & 0.19 & 0.13 & 0.26 \\
\hline $\mathrm{C} 16: 1 \mathrm{t}$ & 0.02 & 0.03 & 0.03 & 0.04 \\
\hline $\mathrm{C} 17: 1 \mathrm{c}$ & 0.10 & 0.15 & 0.11 & 0.22 \\
\hline $\mathrm{C} 17: 1 \mathrm{t}$ & 0.04 & 0.06 & 0.04 & 0.08 \\
\hline $\mathrm{C} 18: 1 \mathrm{c}$ & 2.87 & 4.42 & 3.07 & 5.85 \\
\hline $\mathrm{C} 18: 1 \mathrm{t}$ & 0.21 & 0.32 & 0.23 & 0.43 \\
\hline C20:1 & 0.02 & 0.04 & 0.03 & 0.06 \\
\hline C22:1 & 0.03 & 0.05 & 0.04 & 0.08 \\
\hline $\mathrm{C} 18: 2$ & 0.19 & 0.29 & 0.21 & 0.41 \\
\hline C18:3 & 0.03 & 0.05 & 0.04 & 0.07 \\
\hline t10, c12 CLA & 0.01 & 0.03 & 0.02 & 0.04 \\
\hline c9, t11 CLA & 0.04 & 0.07 & 0.05 & 0.09 \\
\hline C20:4 & 0.02 & 0.04 & 0.03 & 0.05 \\
\hline SFA & 3.64 & 5.62 & 3.95 & 7.56 \\
\hline MUFA & 3.42 & 5.28 & 3.70 & 7.05 \\
\hline PUFA & 0.29 & 0.48 & 0.35 & 0.66 \\
\hline Total FA & 7.35 & 11.38 & 8.00 & 15.27 \\
\hline
\end{tabular}


Table 5. Mean fatty acid composition ( $\mathrm{g} / 100 \mathrm{~g}$ of sample) of Bull's tongue determined by selected methods.

\begin{tabular}{|c|c|c|c|c|}
\hline FAME & sox & Acid Hydrolysis & $\mathrm{B} \& \mathrm{D}$ & FOL \\
\hline $\mathrm{C} 8: 0$ & n.a. & n.a. & n.a. & n.a. \\
\hline $\mathrm{C} 10: 0$ & n.a. & n.a. & n.a. & n.a. \\
\hline $\mathrm{C} 12: 0$ & n.a. & n.a. & n.a. & n.a. \\
\hline C14:0 & 0.09 & 0.19 & 0.12 & 0.18 \\
\hline $\mathrm{C} 15: 0$ (iso) & 0.01 & 0.04 & 0.03 & 0.04 \\
\hline C15:0 (anteiso) & 0.05 & 0.11 & 0.08 & 0.12 \\
\hline C15:0 & 0.08 & 0.17 & 0.12 & 0.18 \\
\hline $\mathrm{C} 16: 0$ & 1.57 & 3.34 & 2.09 & 3.09 \\
\hline $\mathrm{C} 17: 0$ (iso) & 0.03 & 0.08 & 0.05 & 0.07 \\
\hline C17:0 (anteiso) & 0.08 & 0.19 & 0.12 & 0.18 \\
\hline $\mathrm{C} 17: 0$ & 0.22 & 0.46 & 0.29 & 0.44 \\
\hline C18:0 & 1.31 & 2.77 & 1.73 & 2.56 \\
\hline C20:0 & 0.02 & 0.05 & 0.04 & 0.06 \\
\hline $\mathrm{C} 22: 0$ & n.a. & n.a. & n.a. & n.a. \\
\hline C14:1 & 0.01 & 0.01 & 0.01 & 0.02 \\
\hline $\mathrm{C} 16: 1 \mathrm{c}$ & 0.22 & 0.46 & 0.29 & 0.44 \\
\hline $\mathrm{C} 16: 1 \mathrm{t}$ & 0.04 & 0.08 & 0.06 & 0.08 \\
\hline $\mathrm{C} 17: 1 \mathrm{c}$ & 0.06 & 0.14 & 0.09 & 0.13 \\
\hline $\mathrm{C} 17: 1 \mathrm{t}$ & 0.20 & 0.43 & 0.28 & 0.42 \\
\hline $\mathrm{C} 18: 1 \mathrm{c}$ & 2.26 & 4.83 & 3.02 & 4.48 \\
\hline $\mathrm{C} 18: 1 \mathrm{t}$ & 0.25 & 0.52 & 0.33 & 0.47 \\
\hline C20:1 & 0.03 & 0.06 & 0.04 & 0.06 \\
\hline $\mathrm{C} 22: 1$ & 0.02 & 0.04 & 0.03 & 0.05 \\
\hline C18:2 & 0.17 & 0.36 & 0.23 & 0.34 \\
\hline $\mathrm{C} 18: 3$ & n.a. & 0.02 & 0.01 & 0.02 \\
\hline $\mathrm{t} 10, \mathrm{c} 12 \mathrm{CLA}$ & 0.01 & 0.10 & 0.04 & 0.10 \\
\hline c9, t11 CLA & 0.06 & 0.15 & 0.09 & 0.14 \\
\hline C20:4 & 0.02 & 0.04 & 0.03 & 0.05 \\
\hline SFA & 3.46 & 7.40 & 4.67 & 6.92 \\
\hline MUFA & 3.09 & 6.57 & 4.15 & 6.15 \\
\hline PUFA & 0.26 & 0.67 & 0.40 & 0.65 \\
\hline Total FA & 6.81 & 14.64 & 9.22 & 13.72 \\
\hline
\end{tabular}




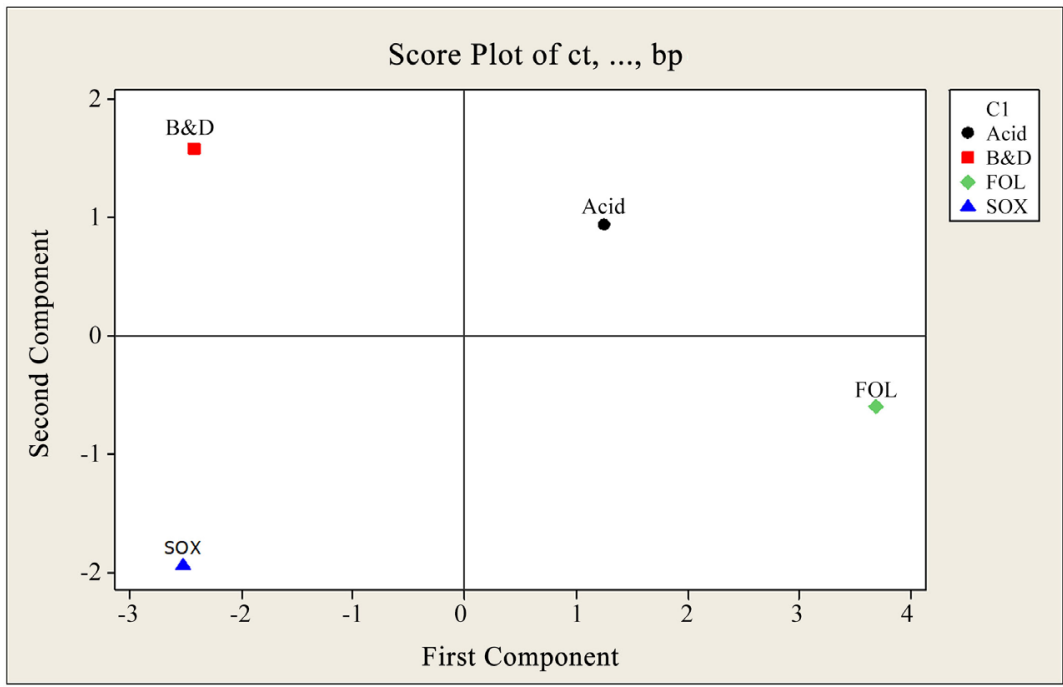

(a)

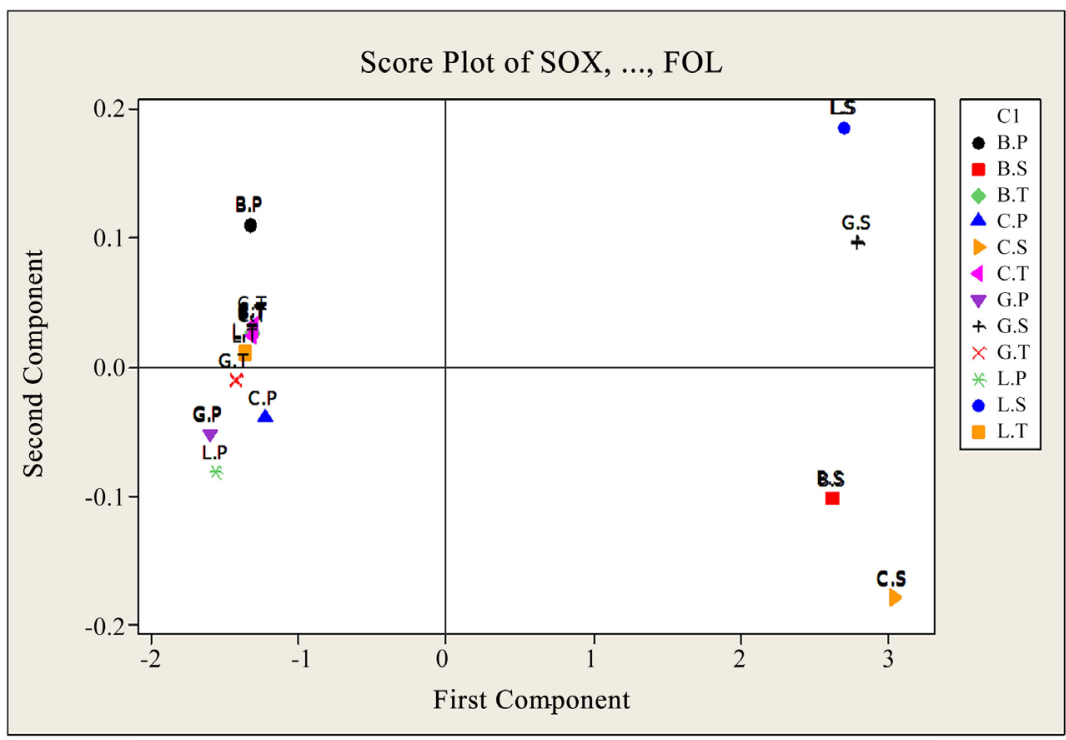

(b)

Figure 2. Principal component analysis score plot for (a) different extraction methods i.e. Soxhlet extract, Acid hydrolysis, Bligh \& Dyer and Folch extract (b) among different animal by-products.

\section{Discussion}

The primary objective of this study was to evaluate different extraction methods for the recovery of fat and fatty acid from selected ruminants' waste products. Out of all studied methods, FOL and acid hydrolysis extracted the highest amount of fat. However, some disparities were observed which might be due to the sample weight or fat content of studied meat products. In the low-fat containing group (pancreas, tongue), the FOL method extracted a higher amount of fat followed by acid hydrolysis. Fat extracted through FOL was similar to the data presented by USDA \& Warren et al., 2020 [23] [24] [25] [26]. While for suet (high fat containing), FOL and SOX performed better than acid hydrolysis \& 
B\&D. For suet of animals, the results varied a little differently, though other methods' extraction efficiency was improved, still the FOL produced the highest results. According to USDA, beef suet has total FAs of around $87 \mathrm{~g} / 100 \mathrm{~g}$, which is closer to current data found for C.S. USDA has reported $94 \mathrm{~g} / 100 \mathrm{~g}$ of lipid in suet of beef [27]. For other animals, no such data was available. The variations in weight might be due to the fact that some other nonnutritive pigments and waxes might also be extracted with fat [14].

The results agree with the reported findings of Iverson et al., (2001), where the author assessed FOL and B\&D methods for various marine products, showing the limitation of B\&D for lipid content, particularly neutral lipids [13]. The lower yield of $B \& D$ is strongly attributed to the amount of methanol and the lower solubility of neutral lipids, which can be improved by varying the amount of methanol according to the sample [28]. Whereas lower lipid extraction by SOX could partly be due to the risk of thermal decomposition of the target compounds, the inefficiency of solvent to hold an excessive quantity of fat, and because the process allows manipulations of limited variables [29]. Another study found poor quality extraction with B\&D as compared to SOX method for rat carcass [30]. In general, the variation between the extraction methods was more distinct in the samples with low-fat content (tongue \& pancreas), as for higher fat samples, the variation was less so. This could be associated with characteristics like moisture and fat content of studied meat products, the nature of the protein network, or even the sample weight [31]. One factor that might be the reason for $\mathrm{B} \& \mathrm{D}$ underperforming is some of the lipids might be lost during the separation of phases. In higher fat samples, the ratio of fatty acid to extracted lipid was greater than lower-fat samples indicating possible concentration dependence [19]. The fatty acids composition of analyzed waste products was dominantly comprised of palmitic, stearic, and oleic acids. These fatty acids have a variety of applications in the production of soaps, cosmetics, and diverse medical uses including drug delivery systems [32] [33] [34].

According to Liping Xiao, from acid hydrolyzed samples, triglycerides and phospholipids are recovered as free fatty acids, on the other hand, for methanol/chloroform extraction method, triglycerides and phospholipids are recovered intact. So, a phospholipid will contribute more to the mass recovery, when extracted by FOL and B\&D rather than acid hydrolysis [35]. Although highly recommended, $\mathrm{B} \& \mathrm{D}$ underperformed, the reason for that might be because the method was developed for low level fat-containing fish in the range of 1-3\%, while our said samples have a higher amount of lipids. So, for each meat product, slight modifications to solvent to sample ratio are necessary.

In one study, the author analyzed 24 different types of food items by comparing gravimetric lipid content with extracted fatty acids and found that overall extracted lipid content was greater than the chromatographically determined Fatty acids. This outcome agrees with our study as well [36]. A food product's energy value is defined by its total Fatty acid contents. Because fatty acids are 
energy stores, that oxidize to release energy. The Earlier findings also elaborate that the food product energy estimates are based on saturation degree, chain length and free/bound FA contents [37]. Instead of crude lipid weight, fatty acid characterization needs to be carried out to determine an accurate assessment of the energy value. Nevertheless, this practice is still in effect, due to lack of sufficient data about various matrices of fatty acids [38] [39]. Current study is the proof that gravimetric lipids are insufficient approximations for the definite energy content in the lipids, as the total extracted lipids in our study varied from $63 \%$ to $90 \%$ of the fatty acid content determined as FAME.

\section{Conclusion}

Slaughterhouse waste was found to be a good source of fat and fatty acids, with the highest fat and fatty acid content was in suet followed by the tongue and pancreas. These products can be rendered to value-added marketable products. Taking the results obtained in this study into consideration, the FOL and the acid hydrolysis method can be recommended for total lipid extraction in meat products. For $B \& D$ method, the original ratio of sample/solvent needs to be adjusted. While for samples containing a higher amount of fat, SOX method can be recommended. However, for further lipid characterization, the latter methods are not recommended because exposure to heat and acid hydrolysis promotes phospholipid hydrolysis, lipid oxidation, and other chemical lipid modifications. Hence, FOL method is a better option for lipid characterization. In the future, using this information, the most suitable method can be applied to appropriate samples for maximum yield.

\section{Acknowledgements}

This work was supported by the Higher Education Commission under the National Research program for Universities (Project 6720).

\section{Conflicts of Interest}

The authors declare that we have no known competing financial interests or personal relationships that could have appeared to influence the work reported in this paper.

\section{References}

[1] Heinz, G. and Hautzinger, P. (2007) Meat Processing Technology for Small-To Medium-Scale Producers (RAP Publication 2007). Food and Agriculture Organization of the United Nations (FAO), Bangkok.

[2] Bah, C.S.F., Bekhit, A.E.-D.A., Carne, A. and McConnell, M.A. (2013) Slaughterhouse Blood: An Emerging Source of Bioactive Compounds. Comprehensive Reviews in Food Science and Food Safety, 12, 314-331. https://doi.org/10.1111/1541-4337.12013

[3] FAO, F.O. (2017) Biannual Report on Global Food Markets. Food and Agriculture 
Organization of the United Nations, Rome, 1-142.

[4] Walsh, C. (2014) The Use of Animal By-Products-AHDB Beef \& Lamb. EBLEX, 2014, Article ID: 130514.

[5] Alfaia, C.M., Alves, S.P., Pestana, J.M., Madeira, M.S., Moreira, O., Santos-Silva, J., Bessa, R.J., Toldrá, F. and Prates, J.A. (2017) Distinct Fatty Acid Composition of Some Edible By-Products from Bovines Fed High or Low Silage Diets. Food Science and Technology International, 23, 209-221.

https://doi.org/10.1177/1082013216674137

[6] Hejnfelt, A. and Angelidaki, I. (2009) Anaerobic Digestion of Slaughterhouse By-Products. Biomass and Bioenergy, 33, 1046-1054. https://doi.org/10.1016/j.biombioe.2009.03.004

[7] Palatsi, J., Viñas, M., Guivernau, M., Fernandez, B. and Flotats, X. (2011) Anaerobic Digestion of Slaughterhouse Waste: Main Process Limitations and Microbial Community Interactions. Bioresource Technology, 102, 2219-2227. https://doi.org/10.1016/j.biortech.2010.09.121

[8] Rajagopal, R., Massé, D.I. and Singh, G. (2013) A Critical Review on Inhibition of Anaerobic Digestion Process by Excess Ammonia. Bioresource Technology, 143, 632-641. https://doi.org/10.1016/j.biortech.2013.06.030

[9] Salminen, E. and Rintala, J. (2002) Anaerobic Digestion of Organic Solid Poultry Slaughterhouse Waste-A Review. Bioresource Technology, 83, 13-26. https://doi.org/10.1016/S0960-8524(01)00199-7

[10] Lynch, S.A., Mullen, A.M., O’Neill, E.E. and García, C.Á. (2017) Harnessing the Potential of Blood Proteins as Functional Ingredients: A Review of the State of the Art in Blood Processing. Comprehensive Reviews in Food Science and Food Safety, 16, 330-344. https://doi.org/10.1111/1541-4337.12254

[11] Lasekan, A., Abu Bakar, F. and Hashim, D. (2013) Potential of Chicken By-Products as Sources of Useful Biological Resources. Waste Management, 33, 552-565. https://doi.org/10.1016/j.wasman.2012.08.001

[12] Markit, I. (2018) Fats and Oils Industry Overview.

[13] Iverson, S.J., Lang, S.L.C. and Cooper, M.H. (2001) Comparison of the Bligh and Dyer and Folch Methods for Total Lipid Determination in a Broad Range of Marine Tissue. Lipids, 36, 1283-1287. https://doi.org/10.1007/s11745-001-0843-0

[14] Silva, P.T., Detmann, E., Filho, S.C.V., Detmann, K.S.C., Barros, L.V., Martins, S.C.V., Morais, L.E. and Costa, V.A.C. (2011) Evaluation of Total and Non-Fatty Ether Extract in Feeds and Cattle Feces Using Two Analytical Methods. Animal Feed Science and Technology, 163, 111-117. https://doi.org/10.1016/j.anifeedsci.2010.10.012

[15] Adhikari, B.B., Chae, M. and Bressler, D.C. (2018) Utilization of Slaughterhouse Waste in Value-Added Applications: Recent Advances in the Development of Wood Adhesives. Polymers, 10, 176. https://doi.org/10.3390/polym10020176

[16] Talpur, F.N., Bhanger, M.I. and Khuhawar, M.Y. (2007) Intramuscular Fatty Acid Profile of Longissimus Dorsi and Semitendinosus Muscle from Kundi Steers Fed on Pasture with Cottonseed Cake Supplement. International Journal of Food Science \& Technology, 42, 1007-1011. https://doi.org/10.1111/j.1365-2621.2006.01451.x

[17] AOAC (2002) Fat Content. In: Official Methods of Analysis, Method 960.39, 17th Edition, Association Official Analytical Chemists, Gaithersburg.

[18] AOAC (2006) Official Methods of Analysis Lipids, Fats and Oils Analysis Total Fat by Acid Hydrolysis Pet Food-Item 24. 17th Edition, Association of Analytical Communities, Gaithersburg, Reference Data: Method 954.02 (4.5.02 or 7.063); 
NFNAP; LIPD; FA.

[19] Habeck, S., Mitchell, B. and Sullivan, D. (2013) Comparison of Fat Extraction Methods for Analysis of Meat. Proceedings AOAC 127 th Annual Meeting \& Exposition, Chicago, 25-28 August 2013.

[20] Bligh, E.G. and Dyer, W.J. (1959) A Rapid Method of Total Lipid Extraction and Purification. Canadian Journal of Biochemistry and Physiology, 37, 911-917. https://doi.org/10.1139/059-099

[21] Folch, J., Lees, M. and Sloane Stanley, G.H. (1957) A Simple Method for the Isolation and Purification of Total Lipides from Animal Tissues. Journal of Biological Chemistry, 226, 497-509. https://doi.org/10.1016/S0021-9258(18)64849-5

[22] David, F., Sandra, P. and Wylie, P.L. (2002) Improving the Analysis of Fatty Acid Methyl Esters Using Retention Time Locked Methods and Retention Time Databases. Agilent Technologies-Application.

[23] USDA (2018) National Nutrient Database for Standard Reference Legacy Release. 133339, Beef, Variety Meats and By-Products, Tongue, Raw.

https://fdc.nal.usda.gov/fdc-app.html\#/food-details/170196/nutrients

[24] USDA (2018) National Nutrient Database for Standard Reference Legacy Release. 17220, Lamb, Variety Meats and By-Products, Tongue, Raw.

https://fdc.nal.usda.gov/fdc-app.html\#/food-details/174366/nutrients

[25] USDA (2018) National Nutrient Database for Standard Reference Legacy Release. 13331, Beef, Variety Meats and By-Products, Pancreas, Raw. https://fdc.nal.usda.gov/fdc-app.html\#/food-details/169452/nutrients

[26] USDA (2018) National Nutrient Database for Standard Reference Legacy Release. 17210, Lamb, Variety Meats and By-Products, Pancreas, Raw. https://fdc.nal.usda.gov/fdc-app.html\#/food-details/172538/nutrients

[27] USDA (2018) National Nutrient Database for Standard Reference Legacy Release. 13335, Beef, Variety Meats and By-Products, Suet, Raw. https://fdc.nal.usda.gov/fdc-app.html\#/food-details/170193/nutrients

[28] Sündermann, A., Eggers, L.F. and Schwudke, D. (2016) Liquid Extraction: Bligh and Dyer. In: Wenk, M.R., Ed., Encyclopedia of Lipidomics, Springer, Dordrecht, 1-4. https://doi.org/10.1007/978-94-007-7864-1_88-1

[29] Danlami Jibrin, M., Arsad, A., Ahmad Zaini Muhammad, A. and Sulaiman, H. (2014) A Comparative Study of Various Oil Extraction Techniques from Plants. Reviews in Chemical Engineering, 30, 605-626.

https://doi.org/10.1515/revce-2013-0038

[30] Brooks, S.P.J., Ratnayake, W.M.N., Lampi, B.J. and Hollywood, R. (1998) Measuring Total Lipid Content in Rat Carcasses: A Comparison of Commonly Employed Extraction Methods. Journal of Agricultural and Food Chemistry, 46, 4214-4217. https://doi.org/10.1021/jf980052w

[31] Pérez-Palacios, T., Ruiz, J., Martín, D., Muriel, E. and Antequera, T. (2008) Comparison of Different Methods for Total Lipid Quantification in Meat and Meat Products. Food Chemistry, 110, 1025-1029.

https://doi.org/10.1016/j.foodchem.2008.03.026

[32] Carta, G., Murru, E., Banni, S. and Manca, C. (2017) Palmitic Acid: Physiological Role, Metabolism and Nutritional Implications. Frontiers in Physiology, 8, 902. https://doi.org/10.3389/fphys.2017.00902

[33] Choulis, N.H. (2011) Chapter 49-Miscellaneous Drugs, Materials, Medical Devices and Techniques. In: Aronson, J.K., Ed., Side Effects of Drugs Annual, Elsevier, Amsterdam, 1009-1029. https://doi.org/10.1016/B978-0-444-53741-6.00049-0 
[34] Hiremath, P., Nuguru, K. and Agrahari, V. (2019) Chapter 8-Material Attributes and Their Impact on Wet Granulation Process Performance. In: Narang, A.S. and Badawy, S.I.F., Eds., Handbook of Pharmaceutical Wet Granulation, Academic Press, Cambridge, 263-315. https://doi.org/10.1016/B978-0-12-810460-6.00012-9

[35] Xiao, L., Mjøs, S.A. and Haugsgjerd, B.O. (2012) Efficiencies of Three Common Lipid Extraction Methods Evaluated by Calculating Mass Balances of the Fatty Acids. Journal of Food Composition and Analysis, 25, 198-207. https://doi.org/10.1016/j.jfca.2011.08.003

[36] Rader, J.I., Angyal, G., O’Dell, R.G., Weaver, C.M., Sheppard, A.J. and Bueno, M.P. (1995) Determination of Total Fat and Saturated Fat in Foods by Packed Column Gas-Liquid Chromatography after Acid Hydrolysis. Food Chemistry, 54, 419-427. https://doi.org/10.1016/0308-8146(95)00054-M

[37] Wiseman, J., Powles, J. and Salvador, F. (1998) Comparison between Pigs and Poultry in the Prediction of the Dietary Energy Value of Fats. Animal Feed Science and Technology, 71, 1-9. https://doi.org/10.1016/S0377-8401(97)00142-9

[38] Aksnes, A. and Opstvedt, J. (1998) Content of Digestible Energy in Fish Feed Ingredients Determined by the Ingredient-Substitution Method. Aquaculture, 161, 45-53. https://doi.org/10.1016/S0044-8486(97)00255-X

[39] Smit, L.E., Schönfeldt, H.C. and Beer, W.H.J.D. (2004) Comparison of the Energy Values of Different Dairy Products Obtained by Various Methods. Journal of Food Composition and Analysis, 17, 361-370. https://doi.org/10.1016/j.jfca.2004.02.006 
Table S6. Mean fatty acid composition (g/100g of sample) of Cow's Suet determined by selected methods.

\begin{tabular}{|c|c|c|c|c|}
\hline FAME & sox & Acid Hydrolysis & B\&D & FOL \\
\hline $\mathrm{C} 8: 0$ & n.a. & n.a. & n.a. & n.a. \\
\hline $\mathrm{C} 10: 0$ & 0.01 & 0.03 & 0.02 & 0.02 \\
\hline $\mathrm{C} 12: 0$ & 0.02 & 0.05 & 0.05 & 0.06 \\
\hline C14:0 & 3.35 & 2.88 & 2.77 & 3.48 \\
\hline C15:0 (iso) & 0.45 & 0.39 & 0.37 & 0.51 \\
\hline C15:0 (anteiso) & 0.64 & 0.59 & 0.56 & 0.70 \\
\hline $\mathrm{C} 15: 0$ & 1.12 & 0.96 & 0.94 & 1.21 \\
\hline C16:0 & 23.09 & 20.47 & 19.08 & 24.43 \\
\hline C17:0 (iso) & 0.11 & 0.08 & 0.09 & 0.15 \\
\hline C17:0 (anteiso) & 0.06 & 0.06 & 0.06 & 0.08 \\
\hline $\mathrm{C} 17: 0$ & 1.95 & 1.78 & 1.69 & 2.16 \\
\hline C18:0 & 28.19 & 25.09 & 23.52 & 29.88 \\
\hline C20:0 & 0.46 & 0.38 & 0.36 & 0.49 \\
\hline $\mathrm{C} 22: 0$ & 0.23 & 0.20 & 0.21 & 0.25 \\
\hline C14:1 & 0.23 & 0.19 & 0.19 & 0.24 \\
\hline $\mathrm{C} 16: 1 \mathrm{c}$ & 0.67 & 0.58 & 0.56 & 0.73 \\
\hline $\mathrm{C} 16: 1 \mathrm{t}$ & 0.48 & 0.47 & 0.42 & 0.51 \\
\hline $\mathrm{C} 17: 1 \mathrm{c}$ & 1.19 & 1.25 & 1.21 & 1.54 \\
\hline $\mathrm{C} 17: 1 \mathrm{t}$ & 0.51 & 0.45 & 0.40 & 0.51 \\
\hline $\mathrm{C} 18: 1 \mathrm{c}$ & 12.07 & 10.71 & 10.03 & 12.76 \\
\hline $\mathrm{C} 18: 1 \mathrm{t}$ & 3.55 & 3.59 & 3.06 & 3.57 \\
\hline C20:1 & 0.44 & 0.37 & 0.35 & 0.46 \\
\hline C22:1 & 0.09 & 0.06 & 0.07 & 0.12 \\
\hline C18:2 & 0.74 & 0.59 & 0.59 & 0.80 \\
\hline C18:3 & 0.08 & 0.06 & 0.09 & 0.08 \\
\hline $\mathrm{t} 10, \mathrm{c} 12 \mathrm{CLA}$ & 0.09 & 0.11 & 0.11 & 0.19 \\
\hline c9, t11 CLA & 0.41 & 0.35 & 0.34 & 0.41 \\
\hline C20:4 & 0.09 & 0.20 & 0.19 & 0.24 \\
\hline SFA & 59.68 & 52.96 & 49.72 & 63.42 \\
\hline MUFA & 19.23 & 17.67 & 16.29 & 20.44 \\
\hline PUFA & 1.41 & 1.31 & 1.32 & 1.72 \\
\hline Total FA & 80.32 & 71.94 & 67.33 & 85.58 \\
\hline
\end{tabular}


Table S7. Mean fatty acid composition (g/100g of sample) of Goat's Suet determined by selected methods.

\begin{tabular}{|c|c|c|c|c|}
\hline FAME & sox & Acid Hydrolysis & B\&D & FOL \\
\hline C8:0 & n.a. & n.a. & n.a. & n.a. \\
\hline C10:0 & n.a. & 0.01 & n.a. & n.a. \\
\hline C12:0 & 0.01 & 0.02 & 0.02 & 0.04 \\
\hline $\mathrm{C} 14: 0$ & 0.87 & 0.89 & 0.74 & 1.04 \\
\hline C15:0 (iso) & 0.03 & 0.07 & 0.05 & 0.09 \\
\hline C15:0 (anteiso) & 0.13 & 0.16 & 0.12 & 0.19 \\
\hline C15:0 & 0.38 & 0.38 & 0.34 & 0.47 \\
\hline C16:0 & 15.69 & 15.67 & 12.64 & 17.68 \\
\hline C17:0 (iso) & 0.11 & 0.13 & 0.10 & 0.19 \\
\hline C17:0 (anteiso) & 0.14 & 0.16 & 0.13 & 0.22 \\
\hline $\mathrm{C} 17: 0$ & 1.39 & 1.42 & 1.15 & 1.64 \\
\hline C18:0 & 33.01 & 32.91 & 26.51 & 37.11 \\
\hline C20:0 & 0.55 & 0.55 & 0.46 & 0.68 \\
\hline C22:0 & 0.09 & 0.09 & 0.08 & 0.12 \\
\hline $\mathrm{C} 14: 1$ & 0.02 & 0.01 & 0.05 & 0.07 \\
\hline C16:1 c & 0.10 & 0.11 & 0.09 & 0.15 \\
\hline $\mathrm{C} 16: 1 \mathrm{t}$ & 0.02 & 0.02 & 0.02 & 0.06 \\
\hline $\mathrm{C} 17: 1 \mathrm{c}$ & 0.08 & 0.08 & 0.09 & 0.16 \\
\hline $\mathrm{C} 17: 1 \mathrm{t}$ & 0.02 & 0.02 & 0.05 & 0.05 \\
\hline $\mathrm{C} 18: 1 \mathrm{c}$ & 16.33 & 16.26 & 13.11 & 18.33 \\
\hline $\mathrm{C} 18: 1 \mathrm{t}$ & 3.78 & 3.78 & 3.08 & 4.34 \\
\hline C20:1 & 0.14 & 0.15 & 0.12 & 0.18 \\
\hline $\mathrm{C} 22: 1$ & 0.06 & 0.09 & 0.07 & 0.12 \\
\hline C18:2 & 0.44 & 0.48 & 0.40 & 0.56 \\
\hline C18:3 & 0.16 & 0.19 & 0.14 & 0.24 \\
\hline $\mathrm{t} 10, \mathrm{c} 12 \mathrm{CLA}$ & 0.01 & 0.04 & 0.04 & 0.07 \\
\hline c9, t11 CLA & 0.12 & 0.12 & 0.13 & 0.19 \\
\hline C20:4 & 0.03 & 0.04 & 0.04 & 0.05 \\
\hline SFA & 52.4 & 52.46 & 42.34 & 59.47 \\
\hline MUFA & 20.55 & 20.52 & 16.68 & 23.46 \\
\hline PUFA & 0.76 & 0.87 & 0.75 & 1.11 \\
\hline Total FA & 73.71 & 73.85 & 59.77 & 84.04 \\
\hline
\end{tabular}


Table S8. Mean fatty acid composition (g/100g of sample) of Lamb's Suet determined by selected methods.

\begin{tabular}{|c|c|c|c|c|}
\hline FAME & sox & Acid Hydrolysis & B\&D & FOL \\
\hline $\mathrm{C} 8: 0$ & 0.21 & 0.23 & 0.17 & 0.27 \\
\hline C10:0 & 0.16 & 0.18 & 0.14 & 0.22 \\
\hline $\mathrm{C} 12: 0$ & 0.14 & 0.16 & 0.13 & 0.18 \\
\hline C14:0 & 1.44 & 1.46 & 1.10 & 1.66 \\
\hline C15:0 (iso) & 0.25 & 0.24 & 0.20 & 0.31 \\
\hline C15:0 (anteiso) & 0.24 & 0.26 & 0.18 & 0.27 \\
\hline C15:0 & 0.40 & 0.42 & 0.34 & 0.51 \\
\hline $\mathrm{C} 16: 0$ & 16.79 & 16.76 & 12.79 & 18.91 \\
\hline C17:0 (iso) & 0.19 & 0.19 & 0.16 & 0.27 \\
\hline C17:0 (anteiso) & 0.16 & 0.16 & 0.15 & 0.25 \\
\hline $\mathrm{C} 17: 0$ & 1.11 & 1.13 & 0.87 & 1.34 \\
\hline C18:0 & 22.01 & 22.01 & 16.78 & 24.79 \\
\hline $\mathrm{C} 20: 0$ & 0.17 & 0.17 & 0.13 & 0.21 \\
\hline $\mathrm{C} 22: 0$ & 0.06 & 0.06 & 0.05 & 0.11 \\
\hline C14:1 & 0.04 & 0.04 & 0.04 & 0.07 \\
\hline $\mathrm{C} 16: 1 \mathrm{c}$ & 0.62 & 0.65 & 0.48 & 0.73 \\
\hline $\mathrm{C} 16: 1 \mathrm{t}$ & 0.24 & 0.27 & 0.23 & 0.36 \\
\hline $\mathrm{C} 17: 1 \mathrm{c}$ & 0.93 & 0.95 & 0.76 & 1.12 \\
\hline $\mathrm{C} 17: 1 \mathrm{t}$ & 0.42 & 0.43 & 0.34 & 0.53 \\
\hline $\mathrm{C} 18: 1 \mathrm{c}$ & 20.35 & 20.36 & 15.54 & 22.95 \\
\hline $\mathrm{C} 18: 1 \mathrm{t}$ & 4.29 & 4.29 & 3.31 & 4.87 \\
\hline $\mathrm{C} 20: 1$ & 0.22 & 0.24 & 0.18 & 0.29 \\
\hline $\mathrm{C} 22: 1$ & 0.34 & 0.36 & 0.28 & 0.43 \\
\hline $\mathrm{C} 18: 2$ & 1.40 & 1.41 & 1.09 & 1.62 \\
\hline C18:3 & 0.25 & 0.27 & 0.21 & 0.32 \\
\hline $\mathrm{t} 10, \mathrm{c} 12 \mathrm{CLA}$ & 0.24 & 0.27 & 0.21 & 0.29 \\
\hline c9, t11 CLA & 0.28 & 0.29 & 0.22 & 0.35 \\
\hline C20:4 & 0.15 & 0.18 & 0.13 & 0.21 \\
\hline SFA & 43.33 & 43.43 & 33.19 & 49.30 \\
\hline MUFA & 27.45 & 27.59 & 21.16 & 31.35 \\
\hline PUFA & 2.32 & 2.42 & 1.86 & 2.79 \\
\hline Total FA & 73.10 & 73.44 & 56.21 & 83.44 \\
\hline
\end{tabular}


Table S9. Mean fatty acid composition (g/100g of sample) of Bull's Suet determined by selected methods.

\begin{tabular}{|c|c|c|c|c|}
\hline FAME & sox & Acid Hydrolysis & $B \& D$ & FOL \\
\hline C8:0 & n.a. & n.a. & n.a. & n.a. \\
\hline $\mathrm{C} 10: 0$ & n.a. & n.a. & n.a. & n.a. \\
\hline $\mathrm{C} 12: 0$ & 0.01 & 0.03 & 0.03 & 0.05 \\
\hline C14:0 & 1.65 & 1.61 & 1.43 & 1.80 \\
\hline C15:0 (iso) & 0.24 & 0.25 & 0.22 & 0.29 \\
\hline C15:0 (anteiso) & 0.62 & 0.63 & 0.57 & 0.73 \\
\hline $\mathrm{C} 15: 0$ & 1.01 & 0.99 & 0.88 & 1.12 \\
\hline $\mathrm{C} 16: 0$ & 19.44 & 18.76 & 16.49 & 20.47 \\
\hline C17:0 (iso) & 0.32 & 0.34 & 0.29 & 0.38 \\
\hline C17:0 (anteiso) & 0.39 & 0.41 & 0.41 & 0.49 \\
\hline $\mathrm{C} 17: 0$ & 1.58 & 1.55 & 1.37 & 1.74 \\
\hline C18:0 & 27.4 & 26.43 & 23.26 & 28.84 \\
\hline C20:0 & 0.23 & 0.24 & 0.23 & 0.29 \\
\hline C22:0 & 0.02 & 0.03 & 0.05 & 0.07 \\
\hline C14:1 & 0.09 & 0.09 & 0.09 & 0.13 \\
\hline $\mathrm{C} 16: 1 \mathrm{c}$ & 0.56 & 0.56 & 0.50 & 0.64 \\
\hline $\mathrm{C} 16: 1 \mathrm{t}$ & 0.22 & 0.23 & 0.21 & 0.27 \\
\hline $\mathrm{C} 17: 1 \mathrm{c}$ & 1.14 & 1.13 & 0.99 & 1.25 \\
\hline $\mathrm{C} 17: 1 \mathrm{t}$ & 0.35 & 0.35 & 0.33 & 0.44 \\
\hline $\mathrm{C} 18: 1 \mathrm{c}$ & 12.59 & 12.17 & 10.73 & 13.30 \\
\hline $\mathrm{C} 18: 1 \mathrm{t}$ & 2.12 & 2.06 & 1.82 & 2.26 \\
\hline C20:1 & 0.28 & 0.29 & 0.28 & 0.35 \\
\hline $\mathrm{C} 22: 1$ & 0.18 & 0.19 & 0.19 & 0.26 \\
\hline C18:2 & 0.72 & 0.71 & 0.65 & 0.84 \\
\hline C18:3 & 0.28 & 0.27 & 0.25 & 0.33 \\
\hline $\mathrm{t} 10, \mathrm{c} 12 \mathrm{CLA}$ & 0.04 & 0.06 & 0.08 & 0.12 \\
\hline $\mathrm{c} 9, \mathrm{t} 11 \mathrm{CLA}$ & 0.17 & 0.18 & 0.17 & 0.24 \\
\hline C20:4 & 0.11 & 0.12 & 0.12 & 0.17 \\
\hline SFA & 52.91 & 51.27 & 45.23 & 56.27 \\
\hline MUFA & 17.53 & 17.07 & 15.14 & 18.90 \\
\hline PUFA & 1.32 & 1.34 & 1.27 & 1.70 \\
\hline Total FA & 71.76 & 69.68 & 61.64 & 76.87 \\
\hline
\end{tabular}


Table S10. Mean fatty acid composition (g/100g of sample) of Cow's Pancreas determined by selected methods.

\begin{tabular}{|c|c|c|c|c|}
\hline FAME & sox & Acid Hydrolysis & B\&D & FOL \\
\hline C8:0 & 0.03 & n.a. & 0.05 & 0.07 \\
\hline $\mathrm{C} 10: 0$ & n.a. & n.a. & n.a. & n.a. \\
\hline $\mathrm{C} 12: 0$ & n.a. & n.a. & n.a. & n.a. \\
\hline C14:0 & 0.13 & 0.21 & 0.17 & 0.25 \\
\hline C15:0 (iso) & n.a. & n.a. & n.a. & n.a. \\
\hline C15:0 (anteiso) & n.a. & n.a. & n.a. & n.a. \\
\hline C15:0 & 0.06 & 0.09 & 0.07 & 0.11 \\
\hline $\mathrm{C} 16: 0$ & 2.30 & 3.45 & 2.93 & 4.16 \\
\hline $\mathrm{C} 17: 0$ (iso) & n.a. & n.a. & n.a. & n.a. \\
\hline C17:0 (anteiso) & n.a. & n.a. & n.a. & n.a. \\
\hline $\mathrm{C} 17: 0$ & 0.18 & 0.28 & 0.23 & 0.33 \\
\hline C18:0 & 3.02 & 4.55 & 3.82 & 5.43 \\
\hline C20:0 & 0.06 & 0.11 & 0.08 & 0.12 \\
\hline C22:0 & 0.001 & 0.001 & 0.002 & 0.001 \\
\hline C14:1 & n.a. & n.a. & n.a. & n.a. \\
\hline $\mathrm{C} 16: 1 \mathrm{c}$ & 0.06 & 0.09 & 0.07 & 0.10 \\
\hline $\mathrm{C} 16: 1 \mathrm{t}$ & 0.02 & 0.03 & 0.02 & 0.03 \\
\hline $\mathrm{C} 17: 1 \mathrm{c}$ & 0.12 & 0.20 & 0.16 & 0.24 \\
\hline $\mathrm{C} 17: 1 \mathrm{t}$ & 0.10 & 0.16 & 0.13 & 0.18 \\
\hline $\mathrm{C} 18: 1 \mathrm{c}$ & 2.06 & 3.19 & 2.70 & 3.86 \\
\hline $\mathrm{C} 18: 1 \mathrm{t}$ & 0.28 & 0.43 & 0.34 & 0.49 \\
\hline C20:1 & 0.05 & 0.09 & 0.06 & 0.09 \\
\hline $\mathrm{C} 22: 1$ & 0.01 & 0.03 & 0.02 & 0.03 \\
\hline C18:2 & 0.09 & 0.15 & 0.13 & 0.18 \\
\hline C18:3 & 0.04 & 0.07 & 0.06 & 0.08 \\
\hline $\mathrm{t} 10, \mathrm{c} 12 \mathrm{CLA}$ & 0.04 & 0.08 & 0.05 & 0.07 \\
\hline c9, t11 CLA & 0.07 & 0.12 & 0.10 & 0.14 \\
\hline C20:4 & 0.04 & 0.09 & 0.06 & 0.102 \\
\hline SFA & 5.78 & 8.76 & 7.35 & 10.47 \\
\hline MUFA & 2.70 & 4.22 & 3.50 & 5.02 \\
\hline PUFA & 0.28 & 0.51 & 0.40 & 0.57 \\
\hline Total FA & 8.76 & 13.49 & 11.25 & 16.06 \\
\hline
\end{tabular}


Table S11. Mean fatty acid composition (g/100g of sample) of Goat's Pancreas determined by selected methods.

\begin{tabular}{|c|c|c|c|c|}
\hline FAME & SOX & Acid Hydrolysis & B\&D & FOL \\
\hline C8:0 & 0.05 & 0.09 & 0.06 & 0.09 \\
\hline $\mathrm{C} 10: 0$ & 0.07 & 0.12 & 0.08 & 0.13 \\
\hline $\mathrm{C} 12: 0$ & 0.09 & 0.15 & 0.11 & 0.16 \\
\hline C14:0 & 0.39 & 0.63 & 0.47 & 0.67 \\
\hline C15:0 (iso) & n.a. & n.a. & n.a. & n.a. \\
\hline C15:0 (anteiso) & n.a. & n.a. & n.a. & n.a. \\
\hline C15:0 & 0.04 & 0.07 & 0.05 & 0.08 \\
\hline $\mathrm{C} 16: 0$ & 1.45 & 2.38 & 1.74 & 2.52 \\
\hline C17:0 (iso) & 0.06 & 0.12 & 0.08 & 0.12 \\
\hline C17:0 (anteiso) & n.a. & n.a. & n.a. & n.a. \\
\hline $\mathrm{C} 17: 0$ & 0.04 & 0.07 & 0.05 & 0.08 \\
\hline C18:0 & 0.65 & 1.07 & 0.79 & 1.14 \\
\hline C20:0 & 0.06 & 0.11 & 0.08 & 0.11 \\
\hline C22:0 & n.a. & n.a. & n.a. & n.a. \\
\hline C14:1 & n.a. & n.a. & n.a. & n.a. \\
\hline $\mathrm{C} 16: 1 \mathrm{c}$ & 0.05 & 0.10 & 0.07 & 0.12 \\
\hline $\mathrm{C} 16: 1 \mathrm{t}$ & 0.03 & 0.06 & 0.04 & 0.06 \\
\hline $\mathrm{C} 17: 1 \mathrm{c}$ & 0.07 & 0.08 & 0.06 & 0.08 \\
\hline $\mathrm{C} 17: 1 \mathrm{t}$ & 0.03 & 0.05 & 0.03 & 0.05 \\
\hline $\mathrm{C} 18: 1 \mathrm{c}$ & 1.00 & 1.63 & 1.20 & 1.74 \\
\hline $\mathrm{C} 18: 1 \mathrm{t}$ & 0.20 & 0.33 & 0.25 & 0.36 \\
\hline C20:1 & 0.04 & 0.09 & 0.06 & 0.09 \\
\hline C22:1 & 0.001 & 0.004 & 0.001 & 0.002 \\
\hline C18:2 & 0.14 & 0.24 & 0.17 & 0.26 \\
\hline $\mathrm{C} 18: 3$ & 0.13 & 0.23 & 0.19 & 0.24 \\
\hline $\mathrm{t} 10, \mathrm{c} 12$ CLA & 0.06 & 0.11 & 0.08 & 0.11 \\
\hline c9, t11 CLA & 0.07 & 0.15 & 0.08 & 0.13 \\
\hline C20:4 & 0.07 & 0.12 & 0.09 & 0.13 \\
\hline SFA & 2.90 & 4.81 & 3.51 & 5.10 \\
\hline MUFA & 1.42 & 2.34 & 1.71 & 2.50 \\
\hline PUFA & 0.47 & 0.85 & 0.61 & 0.87 \\
\hline Total FA & 4.79 & 8.00 & 5.83 & 8.47 \\
\hline
\end{tabular}


Table S12. Mean fatty acid composition (g/100g of sample) of Lamb's Pancreas determined by selected methods.

\begin{tabular}{|c|c|c|c|c|}
\hline FAME & sox & Acid Hydrolysis & B\&D & FOL \\
\hline C8:0 & 0.002 & 0.006 & 0.004 & 0.006 \\
\hline $\mathrm{C} 10: 0$ & 0.02 & 0.03 & 0.03 & 0.04 \\
\hline $\mathrm{C} 12: 0$ & 0.01 & 0.03 & 0.02 & 0.03 \\
\hline $\mathrm{C} 14: 0$ & 0.12 & 0.19 & 0.17 & 0.22 \\
\hline C15:0 (iso) & 0.007 & 0.02 & 0.01 & 0.02 \\
\hline C15:0 (anteiso) & 0.001 & 0.03 & 0.02 & 0.03 \\
\hline C15:0 & 0.02 & 0.04 & 0.03 & 0.05 \\
\hline C16:0 & 1.21 & 1.81 & 1.62 & 2.12 \\
\hline C17:0 (iso) & 0.002 & 0.007 & 0.004 & 0.006 \\
\hline C17:0 (anteiso) & 0.007 & 0.01 & 0.01 & 0.01 \\
\hline $\mathrm{C} 17: 0$ & 0.08 & 0.13 & 0.11 & 0.14 \\
\hline C18:0 & 1.80 & 2.67 & 2.41 & 3.13 \\
\hline C20:0 & 0.008 & 0.02 & 0.01 & 0.02 \\
\hline C22:0 & 0.001 & 0.001 & 0.001 & 0.001 \\
\hline $\mathrm{C} 14: 1$ & 0.003 & 0.008 & 0.003 & 0.01 \\
\hline $\mathrm{C} 16: 1 \mathrm{c}$ & 0.05 & 0.08 & 0.07 & 0.09 \\
\hline $\mathrm{C} 16: 1 \mathrm{t}$ & 0.008 & 0.02 & 0.01 & 0.02 \\
\hline $\mathrm{C} 17: 1 \mathrm{c}$ & 0.06 & 0.09 & 0.08 & 0.10 \\
\hline $\mathrm{C} 17: 1 \mathrm{t}$ & 0.01 & 0.03 & 0.02 & 0.03 \\
\hline C18:1 c & 1.54 & 2.29 & 2.06 & 2.67 \\
\hline $\mathrm{C} 18: 1 \mathrm{t}$ & 0.15 & 0.23 & 0.20 & 0.27 \\
\hline C20:1 & 0.007 & 0.02 & 0.01 & 0.02 \\
\hline C22:1 & 0.03 & 0.05 & 0.04 & 0.05 \\
\hline C18:2 & 0.08 & 0.12 & 0.10 & 0.13 \\
\hline $\mathrm{C} 18: 3$ & 0.007 & 0.02 & 0.01 & 0.02 \\
\hline $\mathrm{t} 10, \mathrm{c} 12 \mathrm{CLA}$ & 0.006 & 0.01 & 0.01 & 0.01 \\
\hline c9, t11 CLA & 0.007 & 0.01 & 0.01 & 0.02 \\
\hline C20:4 & 0.001 & 0.006 & 0.004 & 0.007 \\
\hline SFA & 3.29 & 4.99 & 4.44 & 5.82 \\
\hline MUFA & 1.85 & 2.82 & 2.49 & 3.26 \\
\hline PUFA & 0.10 & 0.16 & 0.13 & 0.18 \\
\hline Total FA & 5.24 & 7.97 & 7.07 & 9.27 \\
\hline
\end{tabular}


Table S13. Mean fatty acid composition (g/100g of sample) of Bull's Pancreas determined by selected methods.

\begin{tabular}{|c|c|c|c|c|}
\hline FAME & sox & Acid Hydrolysis & $\mathrm{B} \& \mathrm{D}$ & FOL \\
\hline C8:0 & 0.007 & 0.03 & 0.01 & 0.02 \\
\hline $\mathrm{C} 10: 0$ & n.a. & n.a. & n.a. & n.a. \\
\hline $\mathrm{C} 12: 0$ & n.a. & n.a. & n.a. & n.a. \\
\hline $\mathrm{C} 14: 0$ & 0.09 & 0.25 & 0.12 & 0.24 \\
\hline $\mathrm{C} 15: 0$ (iso) & n.a. & n.a. & n.a. & n.a. \\
\hline C15:0 (anteiso) & n.a. & n.a. & n.a. & n.a. \\
\hline $\mathrm{C} 15: 0$ & 0.02 & 0.07 & 0.03 & 0.06 \\
\hline $\mathrm{C} 16: 0$ & 1.8 & 4.51 & 2.20 & 4.43 \\
\hline $\mathrm{C} 17: 0$ (iso) & n.a. & n.a. & n.a. & n.a. \\
\hline C17:0 (anteiso) & n.a. & n.a. & n.a. & n.a. \\
\hline $\mathrm{C} 17: 0$ & 0.09 & 0.23 & 0.11 & 0.22 \\
\hline C18:0 & 2.03 & 5.09 & 2.48 & 4.99 \\
\hline C20:0 & 0.02 & 0.06 & 0.03 & 0.06 \\
\hline C22:0 & n.a. & n.a. & n.a. & n.a. \\
\hline C14:1 & n.a. & n.a. & n.a. & n.a. \\
\hline $\mathrm{C} 16: 1 \mathrm{c}$ & 0.09 & 0.25 & 0.12 & 0.25 \\
\hline $\mathrm{C} 16: 1 \mathrm{t}$ & 0.03 & 0.08 & 0.03 & 0.08 \\
\hline $\mathrm{C} 17: 1 \mathrm{c}$ & 0.07 & 0.17 & 0.08 & 0.17 \\
\hline $\mathrm{C} 17: 1 \mathrm{t}$ & 0.03 & 0.09 & 0.04 & 0.07 \\
\hline $\mathrm{C} 18: 1 \mathrm{c}$ & 1.29 & 3.23 & 1.57 & 3.16 \\
\hline $\mathrm{C} 18: 1 \mathrm{t}$ & 0.25 & 0.63 & 0.31 & 0.62 \\
\hline C20:1 & 0.03 & 0.08 & 0.04 & 0.08 \\
\hline $\mathrm{C} 22: 1$ & 0.03 & 0.08 & 0.03 & 0.07 \\
\hline C18:2 & 0.11 & 0.28 & 0.13 & 0.27 \\
\hline C18:3 & 0.01 & 0.02 & 0.01 & 0.02 \\
\hline $\mathrm{t} 10, \mathrm{c} 12 \mathrm{CLA}$ & 0.02 & 0.06 & 0.03 & 0.06 \\
\hline c9, t11 CLA & 0.04 & 0.11 & 0.05 & 0.10 \\
\hline C20:4 & 0.001 & 0.004 & 0.001 & 0.003 \\
\hline SFA & 4.057 & 10.24 & 4.98 & 10.02 \\
\hline MUFA & 1.82 & 4.61 & 2.22 & 4.51 \\
\hline PUFA & 0.181 & 0.47 & 0.22 & 0.45 \\
\hline Total FA & 6.06 & 15.32 & 7.42 & 14.97 \\
\hline
\end{tabular}

